\title{
Being a Doctoral Candidate in Nursing: Reflecting on My Research Journey
}

\author{
Grace Ngundu \\ https://orcid.org/0000-0002-2989-7670 \\ University of South Africa \\ g.ngundu5@gmail.com
}

My doctoral study was indeed a journey - a journey of a thousand miles right from the beginning. I knew I wanted to conduct a qualitative study to get to understand the experiences of HIV positive adolescents. This idea came to mind after I had observed a neighbour's nephew whom I knew was on antiretroviral therapy (ART), but would be admitted to hospital every now and then. As the journey started, it was a very difficult journey for me. The initial struggle was to get ethical clearance for my research proposal. I remember I submitted about four or five times to my supervisors who at one time indicated that they were going to give up on me. I almost gave up as well, but the resilience in me pushed me to do better. Finally, the proposal was accepted with no corrections at all!

As I embarked on the tortuous road of scholarship, I realised that the qualitative method I had chosen required me to do a lot of intensive reading. Afterwards, I wrote a section on phenomenology which I thought was well-written. When the paper came back from my supervisors, I was devastated by their comments. I gave myself a month's break. I picked myself up, read extensively about phenomenology, and in my readings I kept coming across the name "Wertz." I said to myself, let me look for the contact details of this guru in phenomenology and write to him. Not only did he respond-he sent me a copy of one of his books (Wertz et al. 2011; see also Wertz 2005) and indicated that I could always consult him if I had challenges with phenomenology.

I was excited; my journey continued. The journey was truly in motion. I began to focus in earnest on all the comments from my supervisors. I was now enjoying my studies. As I wrote the chapters, I had to articulate my ideas very soundly and they needed to be well-researched. I came to appreciate that phenomenological research goes nowhere without thoughtful writing. I became aware that only by writing can one construct knowledge and in constructing knowledge, we come to write in a more profound manner. This made me realise that the more I wanted to understand my topic, the more I had to read and write!

\section{UNISA $\cong$}


Soon I found myself interviewing research participants. The major learning experience in this phase was how emotional an interview could get. I had in no way anticipated how emotionally involving some of the interviews could become; it was like a reality shock. On a number of occasions, I experienced severe emotional reactions. I was often torn between being a researcher and a counsellor, and was sometimes in danger of being carried away by the participants' stories of pain and suffering. This was a true test of scholarship - in no way intended for the fainthearted! I had to learn to deal with severe emotional reactions, especially when an interviewee broke down and cried loudly and endlessly. On three occasions, I caught myself almost being carried away; I nearly cried and my eyes were teary. After the interviews, it became apparent to me that phenomenological research can truly be an emotionally draining event. While I had a gut feeling that this might happen, the extent of the reactions to some of the participants' stories, especially the emotional weight this levied on me, was unimaginable. Indeed, a journey of a thousand miles had begun.

As I inched forward with the research journey, I experienced yet another surprise during the data analysis phase. Despite having all the transcribed data with me, I was surprised by the fact that I spent nearly four (4) months dwelling on the data of 13 adolescents almost on a daily basis. This level of immersion was totally new to me; it appeared to have no end. Occasionally the feeling that the analysis was moving nowhere would envelop me. Sometimes I wondered, am I really doing the right thing? Despite the apparent stagnation, my supervisors were very encouraging. I began to wonder, is there something wrong with me? I recollected that my frustration was in part because I had imagined that once I had gathered the data, data analysis would be a walk in the park! This later turned out to be a terrible assumption to say the least, because this stage proved to be the most time-consuming. How wrong a young researcher like me could be! As days turned into weeks and weeks into months, every day, I would sit behind my laptop typing away, constantly reading and rereading, copying, cutting, pasting, accepting changes, and deleting, almost incessantly. I would ask, why am I not making progress? Then, suddenly, the cloud of despair vanished, and everything seemed to flow without much hassle after the themes and categories and subcategories became clear. I started to enjoy myself, especially as I wrote the results chapter. I soon discovered that I had more data to support my themes and categories than I needed. This apparent abundance of information overwhelmed me-so much information was suddenly available to tell adolescents' stories. This was completely surprising! The ending became even more enjoyable, because with my supervisors' suggestions each time I submitted a chapter was easier than the last. Finally, the thesis was completed!

\section{References}

Wertz, F. J. 2005. "Phenomenological Research Methods for Counseling Psychology.” Journal of Counseling Psychology 52 (2): 167-77. 
Wertz, F. J., K. Charmaz, L. M. McMullen, R. Josselson, R. Anderson, and E. McSpadden. 2011. Five Ways of Doing Qualitative Analysis. Phenomenological Psychology, Grounded Theory, Discourse Analysis, Narrative Research and Intuitive Inquiry. New York, NY: The Guilford Press. 